\title{
Dietary Intervention of Coconut Liquid to Mitigate the Hyperlipidemia in Rats
}

\section{Amal H Emara ${ }^{1}$, Mona S M Kassem², Areej A Yassin ${ }^{3}$ Asmaa S Abd- elwahed $^{4}$, Hassan M Sobhy ${ }^{5}$, and Hanaa H Elsayed, ${ }^{1}$}

1) Chemistry of Nutrition and metabolism department, National Nutrition Institute (NNI) - Cairo, Egypt

2) Food science department, National Nutrition Institute (NNI) -Cairo, Egypt

3) Nutrition department- Hepatology and Tropical Medicine National Institute-Cairo, Egypt

4) Field Studies and Survey department, National Nutrition Institute (NNI) -Cairo, Egypt

5) Natural resources department- Faculty of African Post Graduated Studies-Cairo, Egypt

Corresponding author: Hanaa H Elsaysd, Email: Hanaa_Hamad2003@yahoo.com Mobil/ +02 01008825869

\section{BRIEF:}

Toconut liquid (CL) is a natural drink that contains many bioactive nutrients. Hyperlipidemia is a heterogeneous group of disorders characterized by abnormal levels of prevalent lipids and lipoproteins. This study aims to evaluate the effect of nutrients in coconut liquid on hyperlipidemia in male albino rats. Animals were divided into four classes: healthy rats, healthy rats that induced hyperlipidemia by a high-fat diet. Rats with hyperlipidemia were supplemented their diet with CL at 2 doses of 100; $500 \mathrm{mg} / \mathrm{kg}$ food for four weeks. The biological parameters were measured (feed intake, body weight gain). The liver functions were (transaminase alanine, transaminase aspartate, and alkaline phosphate). Hyperlipidemia markers were (triglycerides "TG", high-density lipoprotein (HDLc), low-density lipoprotein ( $L D L-c)$, very low-density lipoprotein (VLDL-c), total cholesterol, and atherogenic coefficient "AC"); and histological examination. The results were showed the rats that fed on coconut beverage with two-dose change for better than hyperlipidemic rats of all parameters (biological, biochemical, and histopathological). The overall results show that coconut water $(C W)$ has significant beneficial effects in hyperlipidemic rats.

Key words: Hyperlipidemia - Coconut liquid - Nutritional interventions 
PREFACE

Yong et al.,(2009) reported that the nutritious and medicinal properties of Cocos nucifera have been documented in juice. Misra and Neera (2016) mentioned that coconut sap is a delicious health drink. It is perfect for digestion, facilitates, clears urination, and prevents jaundice. A growing body of evidence demonstrates that coconut liquid has many healthelevate capabilities, including antiinflammatory (Rao and Najam 2016), antibacterial properties (Mandal, et al., 2009), and protects reproductive health (Kunle, et al., 2015). Another study done by Bhagya et al. (2010a) reported that $\mathrm{CW}$ has a beneficial effect on blood pressure levels in rats. In recent years, $\mathrm{CW}$ has been used as a natural sports drink; it contains low levels of carbohydrates, fats, and calories as well as significant amounts of electrolytes (Yong, et al., 2009). Mohamad et al., (2017), confirm that coconut water is the aqueous part of the coconut, containing sugar, inorganic ions, vitamins $\mathrm{C}$ and $\mathrm{B}$ amino acids, and phytohormones. Borse et al. (2007), who supported the previous information that water from the endosperm of coconut can be a good source of minerals and is a natural isotonic with a similar composition to that of saline.

Hyperlipidemia indicates abnormally elevated levels of lipids or lipoproteins in the blood due to abnormal fat metabolism or function, dietary disorders, obesity, genetic diseases such as familial hypercholesterolemia $(\mathrm{FH})$, or other diseases such as diabetes cause it. Patients with hyperlipidemia are about twice as likely to develop cardiovascular disease (CVD) (Sudhakaran et al., 2018). Hyperlipidemia is related to increased oxidative stress causing significant production of oxygen free radicals, which may lead to oxidative modifications in low-density lipoproteins, which present a significant function in the initiation and progression of atherosclerosis and associated cardiovascular diseases (Mclaren et al., 2011).

\section{MATERIALS and METHODS}

\section{Materials:}

Commercial fresh Coconut fruits obtained from the local market. The coconuts were broken carefully, and the liquid endosperm was collected and used for the 
Amal H Emara, Mona S M Kassem, Asmaa S Abd-elwahed, Arij A Yassin and Hanaa H Elsayed

experiment. All kits of the biochemical parameters and chemicals were purchased from ElGomhorya and Morgan Chemical Company, Egypt. Forty weaning male Sprague-Dawley rats $(100 \pm$ $10 \mathrm{~g}$ ) obtained from the animal colony, Helwan Farm, Vaccine and Immunity Organization, Cairo, Egypt. The experimental diets were prepared according to modified of the methods for Reeves et al., (1993).

\section{Methods:}

\section{Chemical Analysis:}

The standard official analytical procedures of AOAC (2000) were used to determine nutrient contents (moisture, protein, fat, minerals and vitamins) while carbohydrates was calculated by deference in coconut liquid all determinations were performed in triplicates.

Carbohydrate (g) =100-(moisture + protein + fat + ash + crud fiber $)$

Total phenolic content (TPC) was determined according to methods of Makkar, (2003) the total phenolic content was expressed in mg of Gallic acid (GA) equivalent per mg of sample.
[2,2- diphenyl 1-1-picrylhrazyl] (DPPH) radical scavenging:

DPPH scavenging performance of coconut according to the method mentioned by Aromatic et al., (2013) with slightly modifications many serial concentrations of the coconut water were putted in test tubes $(1 \mathrm{ml}, 2 \mathrm{ml}, 3 \mathrm{ml}$ and $4 \mathrm{ml})$ performed the analysis in triplicates. $3 \mathrm{~mL}$ of $0.1 \mathrm{mM}$ of methanolic solution of DPPH was added to all test tubes. All the test tubes were vortexed, then left to be stand for $30 \mathrm{~min}$ in the dark at room temperature. The absorption of yellow color appeared against the blank reagent was calculated at $517 \mathrm{~nm}$ spectrophotometer. BHT was used as standard antioxidant. The capacity to scavenge DPPH radical was estimated using the following equation: DPPH scavenging activity (percentage) inhibition) = $\left(\mathrm{A}_{0}-\mathrm{A}_{1}\right) / \mathrm{A}_{0} \mathrm{x} 100$ (Where $A_{0}$ and negative control absorbance $A_{1}$ is sample absorbance).

\section{Biological experiment:}

Experimental rats "forty of Sprague-Dawley healthy adult males" were stayed an individual in wire coops under hygienic conditions [standard lighting (12-h 
daylight and 12-h dim period) and the room preserved at $25 \pm 2{ }^{\circ} \mathrm{C}$ ] throughout the experiment. Food and water were rendered $a d$ libitum and checked two time / week. Rats fed on a standard diet for a week to adaptability before experimentation and approved from the National Nutrition Institute experimental animal unit. The rats were divided into four groups (10 rats per group) as follow: group (1) negative or normal group (-ve): Fed on basal diet only, as a control negative. Group (2) Positive group (+ve): Fed on high fat diet containing (200 g lard, $50 \mathrm{~g}$ cholesterol and 50 $\mathrm{g}$ bile Salt $/ \mathrm{kg}$ modified standard diet instead of corn oil) according to Himber et al., (1995), as a control positive. Treated groups, which were furtherly divided into two groups as follow: Group (3): Fed on hyperlipidemic diet plus $100 \mathrm{mg}$ coconut liquid/ $\mathrm{kg}$ diet. Group (4): Fed on hyperlipidemic diet plus $500 \mathrm{mg}$ coconut liquid/ $\mathrm{kg}$ diet for four weeks. Supplemented with $100 \mathrm{mg}$ and 500 coconut liquid $/ \mathrm{kg}$ diet according to Preetha et al., (2012)

\section{Biological evaluation:}

Animals and diet were weighed twice a week. At the end of the experiment calculated for them as a mean and standard error for each group. Body weight gain $(\mathrm{BWG})=$ final body weight/ $\mathrm{g}-$ initial body weight/g. calculated according to chapman et al., (1959).

\section{Biochemical analysis:}

At the end of the experiment, the rats were fasted overnight and serially anesthetized. Blood was collected in clean dry centrifuge tubes from hepatic portal vein. Liver and kidney have been removed from rats by careful dissection, washed in saline solution $(0.9 \%)$, dried using filter paper and independently weighed. Blood samples were centrifuged for 15 minutes at $3000 \mathrm{rpm}$ to separate the serum. Serum was carefully separated and transferred into dry clean Eppendorf tubes and kept frozen at $-20 \dot{c}$ until analysis. Serum was used for determination of the concentration following parameters: Aminotransferases (ALT and AST) were determined using kits supplied from Setinel $\mathrm{CH}$ according to the method of Bergmeyer et al., (1980). 
Amal H Emara, Mona S M Kassem, Asmaa S Abd-elwahed, Arij A Yassin and Hanaa H Elsayed

Assaying ALP by using SPECTRUM kit according to Tang, et al., (2019). Estimated triglycerides by BIOMED as maintained by Young et al., (1975). Total Cholesterol evaluated by BIOMED on the report of Tietz (1986). Detection high-density lipoprotein HDLCholesterol by BIOMED according to Castelli et al., (1977). Low-density lipoprotein (LDL) and very low-density lipoprotein (VLDL) were calculated by Friedwald (1972) formula, VLDL $=\mathrm{TG} / 5, \mathrm{LDL}=$ Total Cholesterol - (VLDL + HDL). Concentration represented in $\mathrm{mg} / \mathrm{dl}$. Calculation of Atherogenic coefficients (AC) by following equation $(\mathrm{AC})=(\mathrm{T}$. cholesterol - HDL-c) /HDL-c in the opinion of Brehm et al., (2004). Urea determined by using BIOMED as maintained by Vassault, et al., (1999). Creatinine detected by using BIOMED as stated by Young, (2001).

\section{Histopathological Examination of Organs}

Liver and kidney specimen from each rat were fixed in buffered $10 \%$ formalin solution. Organ samples embedded in paraffin wax and prepared for histological examination by sectioning and staining with hematoxylin and eosin, according to Lambergton and Rothstein, (1988).

\section{Statistical analysis}

Data are expressed as Mean \pm SE and was analyzed by one-way analysis of variance (ANOVA) followed by lest significant difference (LSD) multiple comparison tests (SPSS version 11, USA); $\mathrm{P}<0.05$ is considered statistically significant (Bulinski, et al., 2012).

\section{RESULT and DISCUSSION:}

Fresh samples of CL were analyzed for the averages $(\mathrm{g})$ of moisture content, total fat, total carbohydrate, crude protein, ash, and crude fiber. The results were demonstrated in the table (1). The percentage of moisture was $95 \%$ for the fresh samples of coconut water. This result was similar to the finding of Hsiao et al., (2003) they showed that the initial moisture of coconut liquid was 94\%. In addition, George et al., (2004) found that coconut liquid contains $95.3 \%$ water. The total carbohydrates were $2.61 \%$ agreement with Pue et al., (1992), 
who investigated that coconut water contained sugars such as glucose, $\quad$ xylose, and mannose. Young et al., (2009) reported that coconut liquid has a low level of carbohydrates. The total fat was $0.30 \%$ for the fresh coconut, which is comparable to Young et al., (2009) observed that coconut water contained a low level of fat. The ash of coconut liquid was $0.34 \%$ in harmony with Radenahmed et al., (2009) investigated that coconut liquid had a good amount of minerals. The fiber was $0.89 \%$ is confirmed with Nevin and Rajamuhan (2004) and Ge et al., (2006); they reported that coconut liquid lowered total cholesterol, triglycerides, LDL-c, and VLDL-c relative to its fiber content.

The antioxidant activity of fresh coconut water, sample was evaluated by different methods. Free radical scavenging activity of coconut water and total phenolic contents, the data in table (3) show the free radical scavenging activity of coconut samples. Samples had showed an antioxidant activity at different concentrations and that are does a response relationship that activity increased as the concentration boosted. The results revealed that the fresh coconut water had activity against DPPH radical. For the fresh coconut, radical scavenging activity recorded $82 \%, 95 \%, 97 \%$ and $99 \%$ respectively for $1 \mathrm{ml}, 2 \mathrm{ml}, 3 \mathrm{ml}$ and $4 \mathrm{ml}$ of the coconut liquid in the order already mentioned. These are confirmed by the result of the total phenolic contains in table (2) that $1 \mathrm{ml}$ of fresh coconut water contains $50-\mu \mathrm{g}$ total phenolic Equivalent Gallic acid concentration (GAC). The present results are in agreement with Nevin and Rajamuhan (2004), Ripoly and Norat, (2003). Also, Dekal et al., (2009) they reported that coconut liquid had a good antioxidant activity related to its phenolic compounds. Owu et al., (2006) they mentioned that the antioxidant activity of coconut water might be due to many of biological agents such as phenolic compounds. In addition, Jean et al., (2009) showed that coconut water protective versus oxidative status may be due to the present of antioxidant agents it such as vitamins and phenolic compounds. Mohamed et al., (2017) who found the coconut liquid contains phytohormones as well as polyphenol in a good level. In 
addition, Salil and Rajamohan (2000) reported that coconut liquid had active components such as phenol.

The results in table (3) showed the elements content of coconut water. It can be noticed that $\mathrm{K}$ had the highest value fallowed by $\mathrm{P}$ and $\mathrm{Mg}$ but $\mathrm{Na}$ and $\mathrm{Ca}$ showed moderate contents fallowed by Mn content. One of the other hand $\mathrm{Fe}$ and $\mathrm{Zn}$ concentration resulted lower values but the lowest one represented for $\mathrm{Cu}$ level. These are in agreement with Hsiao et al., (2003) who found that coconut contained $\mathrm{Mg}, \mathrm{Mn}, \mathrm{Ca}$ and $\mathrm{K}$ in good levels with low $\mathrm{Na}$.

In the respect of vitamins content in table 4 , vitamin $\mathrm{B}_{1}$ showed the highest content, which was 0.79 for fresh coconut water samples. These values were followed by vitamin B2, which showed $0.581 \mathrm{ppm}$ and vitamin $\mathrm{C}$ with values of $0.592 \mathrm{ppm}$ respectively. Vitamin A or $\beta$ carotene were not found in the coconut water samples. The present results of vitamins are in agreement with USDA (2009) which found that the coconut water contains vitamins $\mathrm{B}_{1}$ (thiamine), $\mathrm{B}_{2}$ (riboflavin) and other vitamins.
Preetha et al., (2012) results that the good effects of coconut water may be due to it contents of many vitamins. It can conclude that coconut water contains low levels of carbohydrates, fat and calories (Young et al., 2009) as well as a good amounts of the inorganic ions , vitamins such as vitamins $C$ and $B$ complex (Mohamed et al., 2017).

Figure "1a\&b" illustrated that there were significant differences for FI and BWG within all groups. Feed intake "FI" in hyperlipidemic animals "G2" as a positive control groups increased with percent change $18 \%$ compare with G1. When rats fed coconut liquid "CL" as a treatment group by doses $100 \mathrm{mg} / \mathrm{kg}$ diet, FI was higher than negative control. While the second dose of CL $(500 \mathrm{mg} / \mathrm{kg}$ diet), FI was the nearest to healthy rats. This due to may be a coconut liquid contains biological effect components possess many medicinal properties and palatability, including antioxidant like vitamins, proteins, metals, amino acids, etc... (Dekel et al., 2009). Epstein et al., (2007) explained greater high-fat diet, which leads to elevated reactivity of the gustatory cortex more feed intake. Shin et al., (2019) reported 
that high -fat diet might be caused leptin resistance with increasing feed intake and/or elevated circulating free fatty acids (FFAs) and a pro-inflammatory cytokine. Davis, et al., (2004) who said that hyperlipidemia individuals experience increase risk for overeating by activation of the mesolimbic reward system in response to feed intake.

Statistical results in figure 1 "a \& b" showed that body weight gain of hyperlipidemia positive control elevated than normal rats with $32 \%$. When rats fed coconut liquid by two doses (100 and 500 mg) supplement BWG was lower significant confront to healthy or positive injury group. In the present investigation gestured towards ameliorating of BGW by $\mathrm{CL}$, this due to CL contain many of vitamin, minerals, and amino acids regarding to study of Preetha, et al., (2012).

Rat model of hyperlipidemia their results of liver function "ALT, AST, and ALP" in figure 2 "a\&b". Findings can be indicated that the liver enzymes in positive groups "G2" were higher than negative control "G1" with percent change 95\%; 45\% and
$196 \%$ respectively. When rats fed $\mathrm{CL}$ as a treatment substance by dose 100 and $500 \mathrm{mg}$, they had lower significantly than positive control and the ratio was close to the average of the normal control group. These data are explained and harmony with chemical analysis in the present study and the phenomenon obtained by Effiong and other, (2010) who can be observed that $\mathrm{CL}$ is rich in the $\mathrm{B}$ complex vitamins, which have a role in the maintenance of liver tissue. Liver function marker enzymes, ALT, AST, and ALP were increased this may be due to leaking out from the tissues and induce the liver injury by free radical mechanism. CL treatment regulated the activity of these enzymes in the liver by antioxidant effect (DeFronzo, 1999). Sandhya and Rajamohan, (2006) who observed that cholesterol enriched diet leads to increased activities of AST, ALT, and ALP in serum of hyperlipidemia. Fortified with CL leads to decreased activity of these enzymes. This phenomenon indicates that fatty infiltration and degeneration of liver cells caused by fat-cholesterol feeding were significantly. Salil and 
Rajamohan, (2000) said CL had active components lowering these enzymes by free amino acid; Larginine, vitamin $\mathrm{C}$, minerals (calcium, magnesium, and potassium).

Finding figure 3 "a \& b" showed the hyperlipidemia group "G2" was increased in urea and creatinine parallel normal control group "G1" by $51 \%$ and $49 \%$ change. CL demonstrated a significant reduction in serum creatinine, urea compared to those in hyperlipidemia rats with decreased the percentage change $25 \%$ and $-32 \%$ respectively in the serum urea. Treatment of hyperlipidemic rats with $\mathrm{CW}$, which could be due to the prevention of protein and nucleic acid degradation by CL.

In hyperlipidemia kidney helps in maintaining homeostasis of the body by reabsorbing important material and excreting waste products (James et al., 2010). Its function is usually assessed by the levels of urea and creatinine in the blood, creatinine being the most specific. Urea is the main product of protein catabolism; it varies directly with protein intake and inversely with the rate of excretion. Renal diseases, which diminish the glomerular filtration, lead to urea retention and a decrease in urea is seen in severe liver disease with the destruction of cells leadings to impairment of the urea cycle (Sheyla et al., 2005). Creatinine is a waste product formed in muscle by creatine metabolism. Creatinine is synthesized in the liver, passes into the circulation and is taken up almost entirely by skeletal muscle. Its retention in the blood is evidence of kidney impairment (Abdul-azeez, et al., 2011).

Hyperlipidemia may lead to an increase of serum creatinine (Geetha et al., 2011). The increase in blood urea observed a close correlation between the increases of creatinine and urea. Likewise, Sheyla et al., (2005), who reported that other molecules that are excreted by the kidneys, such as cystatin e and homocysteine, were also found to increase after coconut liquid therapy (Prakasam, 2004). This suggests that this coconut liquid induce a reduction in glomerular filtration rate. Notably, so that the definitive pathophysiology of hyperlipidemia induced increase in urea and creatinine (Loperito and 
Rajamohan, 2003). The effect of coconut liquid in nephrocalcinosis model of male rats. Some investigators have studied various natural therapeutic agents' in vivo animal models. Bashir et al., (2010) said that coconut water had efficacy on hyperlipidemiainduced nephrocalcinosis in male rats. Prakasam,

(2004) investigated that hyperlipidemia increased the level of serum creatinine and urea indicating renal dysfunction rebalancing of serum urea further unveils the potential effect of coconut water on maintaining renal functioning.

\section{Data in figure 4 "a\&b"} showed Serum lipid profiles of different groups are provided. Lipid profile parameters including the "TG, TC, LDL-c, VLDL-c, and AC" levels in both positive control "G2" were higher significantly than normal rats "G1". HDL-c, concentration in unhealthy groups was lower significantly than in healthy rats. Treatment with CL reversed these changes when compared with G2. These results harmony with, Alatawi and Alshubaily (2021) they found coconut water, has all improved lipid profile by decreasing total-, LDL-c, VLDL-cholesterols, and triglycerides and by increasing HDL-cholesterol in diabetic rats. Figure 4 " $b$ " indicated that the increase and decrease percentage change of lipid profile parameter in the hyperlipidemic group versus normal rats. Hyperlipidemia groups, showed the highest level of percentage change of AC by $427 \%$. CL groups treatment with two doses the highest improvement of percentage change was in AC level compared hyperlipidemic groups by $-81 ;-83 \%$. The amelioration of HDL value by two doses CL groups with percentage change 45 and $48 \%$ versus positive control. The findings of this present study are in conformity with other studies by Sandhya and Rajamohan (2006). CW contains several biologically active components including free amino acid Larginine, ascorbic acid, minerals such as calcium, magnesium and potassium (Sandhya and Rajamohan 2014). Similarly, the presence of L-arginine in CL could have a cardio protective effect through its production of nitric oxide, which favors vasorelaxation (Reddy and Lakshmi, 2014). The ability of $\mathrm{CW}$ in lowering total cholesterol levels was due to the compounds polyphenols, vitamin 
C, and L-arginine (Bhagya et al., 2010, White et al., 2004). The high content of L-arginine in CL can be used to reduce the free radical generation, increase anti-oxidant activity and inhibit the process of lipid peroxidation (Zulaikhah et al., 2015). Constituent's minerals as calcium, magnesium and potassium decrease serum cholesterol and triglycerides levels. Magnesium intake prevents cholesterol deposition in the aortas of mice. The high potassium diet, by protecting endothelial cells can greatly decrease the cholesterol ester deposition during hypercholesterolemia (Sandhya and Rajamohan, 2008). Poly-phenols in lowering total cholesterol levels play role in two ways by reducing fat absorption in the digestive system and increasing fat excretion into feces, so less amount of cholesterol absorption and in the circulation. CW contains both ascorbic acid and vitamins of $B$ group those are nicotinic acid, pantothenic acid, biotin, riboflavin, folic acid and thiamine. Lower blood levels of vitamin B6 and folate can increase the risk for atherosclerosis and other vascular diseases. Vitamin $\mathrm{C}$ is responsible for keeping the activity of cholesterol 7 alpha-hydroxylating system conta-ining cytochrome P450. Decrease in TC and reduced accumulation of TC in the liver, blood plasma, and the arteries caused by the increased activity of cholesterol 7 alpha-hydroxylation system containing cytochrome P450 thus stimulating change cholesterol into bile acids increased (Ginter et al., 1982). The effect on the stimulation of bile acid sequestrants like cholestyramine or pectin strengthen the effects of vitamin C to reduce the solubility of fat and block the absorption of cholesterol. Vitamin $\mathrm{C}$ in $\mathrm{CW}$ proved to have protective activity on HDL cholesterol, playing a role in the process of reverse cholesterol transport. Lecithin transforms cholesterol HDL into mature cholesterol ester. Cholesterol ester in HDL is transferred back to the liver and is then converted into bile acids. Apolipoprotein AI in HDL may alter HDL is oxidized to lecithin. Vitamin $\mathrm{C}$ can increase the ability of AI, so that the process of increasing reverse cholesterol transport (McRae, 2008). Polyphenol aided by trapping of reactive oxygen species in aqueous components such as plasma and 
interstitial fluid of the arterial wall thereby inhibiting LDL oxidation, reversal of cholesterol transport and reducing intestinal absorption of cholesterol (Eckarstein et al., 2002). Miguez et al., (2004) who indicated the CL had lower levels of total cholesterol and triglycerides level in serum and tissues.

\section{Liver histological}

Figure 5 showed that Photo " 1 " shows the normal histological structure of hepatic lobule in the normal group feeding standard diet only. Liver of rat from group 1 showing the normal histological structure of hepatic lobule but photo2: Positive control fed high fat diet; liver of rat showing congestion of central vein and steatosis of hepatocytes. Photo3: Treatment with $100 \mathrm{mg}$ coconut liquid shows a decrease in liver cell degeneration. In the photo4 (treatment with $500 \mathrm{mg}$ coconut liquid) shows cytoplasmic vacuolization of hepatocytes and congestion of the central vein.

Blood tests used for the initial assessment of liver disease include measuring levels of serum (ALT and AST), alkaline phosphatase, and others. The pattern of abnormalities generally points to hepatocellular versus cholestasis liver disease and helps to decide whether the disease is acute or chronic and whether cirrhosis and hepatic failure are present (Ghany et al., 2005). Serum enzyme levels fluctuate widely from normal to moderately abnormal, with values rarely into the high hundreds (Boker et al., 1997). Liver disease "LD" represents a spectrum of clinical illness and morphological changes that range from fatty liver to hepatic inflammation and necrosis (hepatitis) to progressive fibrosis (cirrhosis) (Gremenzi et al., 2006). A reliable history is helpful; this can be difficult. A biochemical clue is the ratio of AST to ALT "2:1 at least" reflecting the low, level of activity of ALT in people with liver disease (Limdi and Hyde, 2003). Sandhya and Rajamohan, (2008) showed that the decrease in the concentration of serum triglyceride in rats fed with coconut water may be due to the increased activity of a lipoprotein lipase in the heart and adipose tissue. Limdi and Hyde, (2003) reported that increases the clearance of the triglyceride-rich lipoprotein, namely the chylomicrons, and VLDL. A 
decreased activity of the lipogenic enzymes e.g. malic enzyme, glucose- 6 -phospate dehydrogenase, isocitrate dehydrogenase in the liver all of which are involved in producing NADPH for fatty acid synthesis also is in line with a decrease of synthetic triglycerides in rats fed with coconut water (Sandhya and Rajamohan, (2008). Sandhya and Rajamohan (2006) observed in histopathological studies revealed that glycogen did accumulate in the hepatocytes in liver particularly who, found that fatty accumulation in the liver was much less in cholesterol-fed rats supplemented with coconut water compared with the control group. In the present study, by gross observation, no fat was observed to accumulate in the liver. Sandhya and Rajamohanin (2008) who, found that rats fed a fat-high cholesterol diet lead to increased activities of serum "AST, ALT, and ALP" while supplementation with coconut water leads to a decreased activity of these enzymes.

\section{Renal histological}

Figure 6 showed photo1: Normal group feeding standard diet only Kidney of rat from group
1 showing the normal histological structure of renal parenchyma. photo2: Positive control fed high fat diet, kidney of rat the congestion of glomerulonephritis and recurrent pulmonary endothelial ovaries appears to be significant as for Photo3: Treatment with $100 \mathrm{mg}$ coconut liquid the congestion of glomerulonephritis and pulmonary disease from endothelial ovaries appears to be minimal. In the photo4 treatment with $500 \mathrm{mg}$ coconut, liquid showing the lack of congestion from glomerulonephritis and recurrent pulmonary endothelial ovaries appears to be significant. Hypercholesterolemia is Lipid abnormalities often accompany and aggravate renal disease, favoring accelerated atherogenesis and "LDL-c" can promote glomerulosclerosis, secondary abnormality's in lipid metabolism (e.g. increased triglycerides and ox-LDL-c, decreased "HDL-c" and lipoprotein (Abrass, 2004) and (Crook et al., 2003). Dyslipidemia may trigger renal injury at an early stage. Experimental studies demonstrated that diet-induced hypercholesterolemia resulted in renal endothelial dysfunction 
(Chade et al., 2003), intracranial inflammation and fibrosis, vascular damage (Chade et al., 2002), microvascular modeling, (Chade et al, .2004) (Bentley et al., 2002) and ultimately glomerulosclerosis (Keane et al., 1988) and that oxidative stress mediated many of these effects. Glomerular mesangial, endothelial, and vascular smooth muscle cells can uptake native and LDL-c, leading to glomerular injury by inducing the formation of foam cells that are as associated with later glomerulosclerosis and interstitial interestingly. Foam cell formation and production of ECM proteins (Roh et al., 1998) and lead to endothelial, tubular, and vascular injury, which may be reflected in proteinuria. (Crook et al., 2003). Oxidized or glycosidase lipoproteins may promote dysfunction, glomerular injury, and interstitial fibrosis in the atherosclerotic kidney (Dom-inguez et al., 2000) and (Guijarro et al., 1995). Furthermore, oxidative stress increases the propensity for renal damage in atherosclerosis by modulating the transcription of growth factors Chade et al., (2002, 2003, and 2004) observed previously that hypercholes- terolemia might increase circulating levels (Chade et al., 2005) and renal uptake of "LDL-c" (Wilson et al., 2003 and Chade et al., 2003).

Lipid metabolism involves the transport of lipid in plasma and the cellular uptake of lipids in cells. The major lipids in plasma are triglycerides, phospholipids, cholesterol, and cholesterol esters, which constitute the lipid moiety of lipoprotein particles. Free fatty acids in plasma are predominantly bound to albumin (Christensen et al., 2002). The major organs for metabolism of lipid are the liver, skeletal muscle, and adipose tissue, which express specific receptors and transport molecules for uptake of the lipids. However, substantial lipid metabolism also takes place in other organs by various cell types, for example macrophages, which have a high capacity uptake of oxidized low-density lipoprotein (Rudenko et al., 2002). The kidney is usually not regarded as an important organ in lipid metabolism because the glomerular filtration barrier prevents large molecules such as lipoprotein particles from being filtered into the pre-urine. Nevertheless, the proximal tubule epithelium is 
equipped with a high-capacity receptor system for uptake of a broad spectrum of ligands, including various apolipoproteins, albumin and other proteins binding lipophilic substances. In accordance with their physiological roles in ligand uptake, functional failure in either of the receptors has severe consequences. Megalin deficiency in mice causes severe malformations and high offspring mortality that is likely due to failed receptor recognition of megalin ligands such as vitamin A binding protein (Christensen et al., 1999), vitamin $\mathrm{D}$ binding protein (Nykjaer et al., 1999) and bone morphogenic protein-4 (Spoelgen et al., 2005). The latter is a signaling protein that is essential for neuro-development and extracellular accumulation of this protein causes defects in mice that are like with deficient megalin expression in the neuroepithelium (Spoelgen et al., 2005). The consequences of failed cubilin and amnion less functions are species dependent. In rodents, both proteins seem essential for embryonic survival (Sahali et al., 1988) and (Kalantry et al., 2001).

Tender coconut water is a common drink in all coconut producing countries. It is a rich source of biologically active components that are reported to possess many beneficial effects. Antioxidant and antithrombotic activities of tender coconut water functional foods and nutraceuticals are becoming a part of everyday life. Plant foods could be considered as functional foods since they are all rich in phytochemicals or nutraceuticals. They are claimed to have a medicinal effect on human health. More rigorously, nutraceuticals demonstrated to have physiological benefits or provide protection against chronic diseases. There is overwhelming epidemiological evidence that diets rich in plant foods are associated with lower incidence of cancer, cardiovascular and other degenerative diseases (Ames $\boldsymbol{e t}$ al., 1993). To some extent, this may be because such diet provides less fat and relatively high content of biologically active nutrients. Several studies have implicated that dietary factors play an important role in the cause and prevention of many diseases including coronary heart diseases (Willet, 1994). 
The histology of the kidney of the Control "G 1 " shows glomerulus with normal capillaries with the Distal Convoluted and Proximal Tubules showing normal cellular structures compared with that of Positive control fed high fat diet with cholesterol rats "G 2" which shows some degeneration of the glomerulus with the presence of tubular cast and signs of chronic inflammation. George et al., (2004) previously reported a damaging effect of positive control fed high fat diet with cholesterol in the glomerulus thereby affecting glomerular filtration rate "GFR". However, these findings were significantly but partially reversed by the concomitant administration of coconut water "G 3,4". This could be explained by (Sandhya and Rajamohan, 2008) who found that the lipid lowering effect in rats fed of coconut water resulted from various mechanisms such as inhibition of intestinal absorption of dietary lipids. The hypo-lipidemic effect of coconut liquid protein is due to the high content of L-arginine (Mini and Rajamohan, 2004).

\section{Conclusion:}

In this study showed the liquid of Coconut ameliorated of hyperlipidemia by bioactive content in it.

\section{REFERENCES}

Abdul-Aziz M; Seema B; Ahmed S; Bikha RD; Memon SA; Ghulam AQ, and Waqas SM (2011):

Investigation in hepatitis B patients with or without diabetes mellitus to determine the impact of anti-oxidant activity; world applied sciences journal 15 (6): 765-771

\section{Abrass CK (2004):}

Cellular lipid metabolism and the role of lipids in progressive renal disease. Am J Nephrol. 24:46-53.

\section{Alatawi KA and Alshubaily FA (2021):}

Coconut products alleviate hyperglycaemic, hyperlipidimic and nephropathy indices in streptozotocininduced diabetic waster rat; Saudi Journal of Biological Sciences 28, 4224-4231

AOAC (2000):

Association of Official Analytical Chemists, 17th 
Amal H Emara, Mona S M Kassem, Asmaa S Abd-elwahed, Arij A Yassin and Hanaa H Elsayed

ED. Of A.O.A.C. international published by A.O.A.C. inter-national Maryland, U.S.A., 1250 pp.

Ames MK; Shigenaga MK and Hagen TM (1993):

Oxidants, antioxidants and the degenerative disease of aging. Proc. Natl. Acad. Sci.U.S.A. 90, 7915-7922.

Aromatic FA; El-mhdwi MF; Aromatic F and Aromatic $O O$ (2013):

Estimation of antioxidant activities of fixed and volatile oils extracted from aromatic (clove). Pelagia Research Library .Der ChemicaSinica, 4(3):120125.

Bashir S; Gilani AH; Siddiqui AA; Pervez S; Khan SR, Sarfaraz NJ, and Shah AJ (2010):

Berberis vulgaris root bark extract prevents hyperoxaluria-induced urolithiasis in rats. Phytother Res.; 24: 1250-5.

Bentley MD; Rodriguez-Porcel M; Lerman A; Sarafov MH;
Romero JC; Pelaez LI; Grande JP Ritman EL and Lerman LO. (2002):

Enhanced renal cortical vascularization in experimental hypercholesterolemia. Kidney Int. 61: 1056-1063

Bergmeyer HU; Horder M and Moss DW (1980):

Provisional recommenddations on IFCC methods for the measurement of catalytic concentrations of enzymes: Revised IFCC Method for aspartate aminotransferase. Clinca Chimca Acta, 24: 720-722.

Bhagya D; Prema L and Rajamohan T (2010):

Tender coconut water maintains the level of electrolytes and renin in fructose-fed hypertensive rats. Int J Biol Med Res; $1: 44-8$.

Bhagya D; Prema L and Rajamohan T (2010a):

Beneficial effects of tender coconut water on blood glucose and lipid levels in experimental hypertension; 
J Cell Tissue Res, 10 (1):

2139-2144.

Boker KH; Dalley G and Bahr MJ, (1997):

Long-term outcome of hepatitis $\mathrm{C}$ virus infection after liver trans-plantation, Hepatology; 25(1):203-10.

\section{Borse B; Rao L; Ramalakshmi K} and Raghavan B (2007):

Chemical composition of volatiles from coconut SAP (neera) and effect of processing; Food Chem, 101: 877-880.

Brehm A; Pfeiler G; Pacini G; Vierhapper $H$ and Roden $M$ (2004):

Relationship between serum lipoprotein ratios and insulin resistance in obesity. Clin Chem. 50:2316-22.

\section{Bulinski A; Butkovsky} O; Sadovnichy V; Shashkin A; Yaskov P; Balatskiy A; Samokhodskaya L and Tkachuk V(2012):

Statistical Methods of SNP

Data Analysis and Applications; Journal of
Statistics Vol.2 No.1, pp. 73-87

Castelli JT; Doyle T; Gordon CG; Hames MC; Hjortland SB Hulley A; Kagan WJ and Zuke I (1977):

HDL cholesterol and other lipids in coronary heart disease. The cooperative lipoprotein phenotyping study; Circulation. 55 (5): 767-72.

Chade AR; Herrmann J; Zhu XY; Krier JD; Lerman A Lerman LO (2005):

Effects of proteasome inhibition in experimental hypercholesterolemia. $J$ Am Soc Nephrol; 16:10051012.

Chade AR; Rodriguez-Porcel M; Herrmann J; Zhu X; Grande JP; Napoli C; Lerman A and Lerman LO.(2004):

Antioxidant intervention blunts renal injury in experimental renovascular disease. J Am Soc Nephrol. 15:958-966.

Chade AR; Rodriguez-Porcel M; Grande JP; Zhu X; Sica V; 
Napoli C; Sawamura T; Textor $\mathrm{SC}$; Lerman A and Lerman LO ( 2003):

Mechanisms of renal structural alterations in combined hypercholesterolemia and renal artery stenosis. Arterioscler Throm $b$ Vasc Biol.; 23:1295-1301

Chade AR; Rodriguez-Porcel M; Grande JP; Krier JD; Lerman A; Romero JC; Napoli C and Lerman LO (2002):

Distinct renal injury in early atherosclerosis and Reno vascular disease. Circulation. 106: 1165 1171.

Chapman DG; Castilla $R$ and Campbell JA (1959):

Evaluation of protein in food. I. A. Method for the determination of protein efficiency ratio. Can. J. Biochem. Phyysiol. 37: 679-686.

Christensen EI; Birn H; and Cubilin M (2002):

Multifunctional endo-cytic receptors. Nat Rev. Mol Cell Biol; 3:258A-268A
Christensen EI; Moskaug JO; Vorum H; Jacobsen C ; Gundersen T E; Nykjaer A; Blomhoff R; Willnow TE and Moestrup S K (1999):

Evidence for an essential role of megalin in transepithelial transport of retinol. J Am Soc Nephrol; 10:685-695.

Crook ED; Thallapureddy A; Migdal S; Flack JM; Greene EL; Salahudeen A; Tucker JK and Taylor HA (2003):

Lipid abnormalities and renal disease: is dyslipidemia a pre-dictor of progression of renal disease? Am J Med Sci.; 325:340-348.

Davis C; Strachan S and Berkson M (2004):

Sensitivity to reward Implications for overeating and overweight. Appetite; 42:131-138.

DeFronzo RA (1999):

Pathogenesis of type 2 diabetes; implications for metformin, Drugs; 58, 
Suppl. 1:29-30, discussion $75-82$.

Dekel Y; Glucksam Y; ElronGross I and Margalit R (2009): Insights into modeling streptozotocin -induced diabetes in ICR mice. $L a b$ Animals, (NY); 38(2):5560.

Dominguez JH; Tang N; Xu W; Evan AP; Siakotos AN; Agarwal R; Walsh J; Deeg M; Pratt JH; March KL; Monnier VM; Weiss MF; Baynes JW and Peterson R (2000):

Studies of renal injury III:

lipid-induced nephropathy in type II diabetes. Kidney Int.; 57:92-104.

Eckarstein V; Noter JR and Assmann G (2002):

High-density lipoproteins and atherosclerosis. Role of cholesterol efflux and reverse cholesterol transport. Arterioscler Thromb Vasc Biol; 21: 13-27.

Effiong G; Ebong P; Eyong E; Uwah $A$ and Ekong $U$ (2010): Amelioration of Chloramphenicol Induced Toxicity in Rats by Coconut Water Effiong, Grace Sylv-ester, Department of Clinical Pharmacy and Biopharmacy, Faculty of Pharmacy, University of Uyo, Uyo- Akwa Ibom State, Nigeria Journal of Applied Sciences Research; 6(4): 331-335.

Epstein LH; Temple JL; Neaderhiser BJ; Salis RJ; Erbe RW and Leddy JJ (2007);

Food reinforcement, the dopamine D2 receptor genotype and energy intake in obese and non-obese humans. Behavioral Neuro-science;121(5):87786.

Friedewald WT; Levy RI and Frerickson DS (1972):

Estimation of the concentration of lowdensity lipoprotein cholesterol in plasma without use of the preparative ultracentrifuge. Clin. Chem., 18: 499-502.

Ge L; Yong J, Tan W and Ong E (2006): 
Amal H Emara, Mona S M Kassem, Asmaa S Abd-elwahed, Arij A Yassin and Hanaa H Elsayed

Determination of cytokinins in coconut (Cocos nucifera L.) water using capillary zone electrophoresis-tandem massspectrometry; Electrophoresis, 27: 2171-2181.

Geetha G; Kalavalarasariel G and Sankar V (2011):

Antidiabetic effect of Achyranthesrubrofusca leaf extracts on alloxan induced diabetic rats; Pak. J. Pharm. Sci., 24(2), 193 199.

George AP; Mellita K; Ibrahim SS; Bahaa M; Ayman S and Wolfgang HM (2004).

Green coconut water for intravenous use: Trace and minor element content. Journal of Trace Element in Experimental Medicine. 17:273:282.

Ghany M; Hoofnagle JH and Harrison'S (2005):

Principle of internal medicine, 16th Edition, New York, NY: McGraw Hill Medical: 1808.
Ginter E; Bobek P; Kubec F; Vozár J and Urbanová D (1982):

Vitamin $\mathrm{C}$ in the control of hypercholesterolemia in man. Int J Vitam Nutr Res Suppl; 23:137-52.

Gremenzi A; Caputo F and Biselli M (2006):

Alcoholic liver disease pathophysiological aspects and risk factors; Alimentary Pharmacology, 24, 1151-1161.

Guijarro C; Kasiske BL; Kim Y; O'Donnell MP; Lee HS and Keane WF (1995):

Early glomerular changes in rats with dietary-induced hypercholestero-lemia. Am JKidney Dis.; 26:152161.

Hsiao G; Shen M; Lin K; Chou C; Tzu N; Lin C; Chou D; Chen $T$ and Sheu $J$ (2003):

Inhibitory activity of kinetin on free radical formation of activated platelets in vitro and on thrombus formation in vivo; Eur. J. Pharmacol. 465: 281-287. 
Himber J; Missano B; Rudling $\mathrm{M}$; Hemes $\mathrm{U}$ and Kempen $\mathrm{HJ}$ (1995):

Effects of stigmastanylphosphocholine (Ro 166532) and lovastatin on lipid and lipoprotein levels and lipoprotein metabolism in the hamster on different diets. J. Lipid Res. 36: 1567-1585.

James F; Glockner M; Gloviczki L; Lilach O; Michael LA; Misra S; Joseph Mc; Grande P and Texto SC (2010):

Preserved Oxygenation

Despite Reduced Blood Flow in Post stenotic Kidneys in Human Atherosclerotic. Renal Artery Stenosis; 55: 961966

Jean W; Yong H; Ge L and Tan $S$ (2009):

The chemical composition and biological properties of coconut; (Cocos nucifera L.) Water, Molecules; 14, 5144-5164.

Kalantry S; Manning S; Haub O; Tomihara-Newberger $C$; Lee
HG; Fangman J; Disteche CM; Manova $K$ and Lacy E (2001):

The amnionless gene, essential for mouse gastrulation, encodes a visceral-endoderm-specific protein with an extracellular cysteine-rich domain. Nat Genet 27:412416.

Keane WF; Kasiske BL and O'Donnell MP (1988):

Lipids and progressive glomerulosclerosis. A model analogous to atherosclerosis. Am J Nephrol. 8: 261-271.

Kunle O; Akindele O; Oyovwi M; Duro M and Raji Y (2015):

Effects of coconut water on reproductive functions in diazole treated Wister rats, FASEB J; 29, 685.1,

Lambergton $S$ and Rothstein $R$ (1988):

Laboratory manual of histology and cytology 2nd Ed. pp.137-140. A.V.I. publishing company, Inc., west port Connecticut, USA.

Limdi J K and Hyde G M (2003): 
Amal H Emara, Mona S M Kassem, Asmaa S Abd-elwahed, Arij A Yassin and Hanaa H Elsayed

Evaluation of abnormal liver function tests, Postgrad Med J; 79:307312.

\section{Loperito LA and Raja-mohan T} (2003):

Hepato-protective and antioxidant effects of coconut water on $\mathrm{CCl}_{4-}$ induced liver injury in rats; Indian J Biochem Biophys, 40: 354-357.

Makker HPS (2003):

Effects and fat of tannins in rumination, animals, adaptation to tannins and strategies to overcome determination effects of feeding tannin- rich feeds Small Rumen. Res. 49(3):241-256.

\section{Mandal S; Dey S; Mandal M;} Sarkar S; Maria S and Franco O (2009):

Identification and structural insights of three novel anti-microbial pep-tides isolated from green coconut water, Peptides; $30,633-637$.
Mclaren J Michael D Ashlin T Ramji D and Cytokines R (2011):

Macrophage lipid metabolism and foam cells: Implications for cardiovascular disease therapy; Prog. Lipid Res., 50 (4):331-347. .

McRae MP (2008):

Vitamin C supplementation lowers serum lowdensity lipoprotein cholesterol and triglycerides: a met analysis of randomized controlled trials. $J$ Chiropr Med; 7(2): 48-58.

Mohamad N; Yeap S; Ky H; Ho W; Boo S; Chua J; Beh B; Sharifuddin S; Long $K$ and Alitheen N (2017):

Dietary coconut water vinegar for improve-ement of obesity-associated inflammation in high-fat-diettreated mice, Food \& Nutrition Research; Vol. 61, 1368322. -

Miguez I; Marino G; Rodriguez $B$ and Taboada C (2004):

Effects of dietary Larginine supplementation on serum lipids and 
Amal H Emara, Mona S M Kassem, Asmaa S Abd-elwahed, Arij A Yassin and Hanaa H Elsayed

intestinal enzyme activities in diabetic rats. J. Physiol. Biochem. 60, 31-37.

Mini S and Rajamohan T (2004): Influence of coconut kernel protein on lipid metabolism in alcohol fed rats. Indian $J$ Exp Biol; 42(1): 53- 57.

\section{Misra B and Neera A (2016):}

The coconut sap: a review in international journal of food science and nutrition; Volume 1; Issue 4; Page No. 35-38.

Nevin KG and Rajamohan $T$ (2004):

Beneficial effects of virgin coconut oil on lipid parameters and in vitro LDL-c oxidation. Clin Biochem, 37: 830-835.

Nykjaer A; Dragun D; Walther D; Vorum H; Jacobsen C; Herz J; Melsen F; Christensen EI and Willnow TE (1999):

An endocytic pathway essential for renal uptake and activation of the steroid 25- $(\mathrm{OH})$ vitamin D-3. Cell; 19, 96 (4):507-515.
Owu D; Antai A; Udofia K; Obembe A; Obasi $\mathrm{K}$ and Eteng M (2006):

Vitamin $\mathrm{C}$ improves basal metabolic rate and lipid profile in alloxan-induced diabetes mellitus in rats. $J$ Biosci., 1(5), 575-579.

Prakasam A; Sethupathy S and Pugalendi KV (2004):

Influence of Casearia esculenta root extract on protein metabolism and marker enzymes in streptozotocin-induced diabetic rats. Polish $J$ Pharmacol Pharm 56: 587593.

Preetha PP; Devi VG and Rajamohan T (2012):

Hypoglycemic and Antioxidant Potential of Coconut Water in Experimental Diabetes. Food \& Function 3, 753-757.

Pue A; Rivu W; Sundarrao C and Singh K (1992):

Preliminary studies on changes in coconut water during maturation of the fruit; Sci. New Guin. 18: 81-84. 
Radenahmad N; Saleh F; Sawangjaroen K; Rundorn W; Withyachumnarnkul B and Connor J (2009):

Young Coconut juice significantly reduces histopathological chan-ges in the brain that is induced by hormonal imbalance: a possible implication to postmenopausal women; Histol Histopathol. 24: 667-674.

\section{Rao S and Najam R (2016):}

Coconut water of different maturity stages ameliorates inflammatory processes in model of inflammation, J. Intercult. Ethno-pharmacol; 5, 244 249.

Reddy EP and Lakshmi TM (2014):

Coconut Water - properties, uses, nutritional benefits in health and wealth and in health and disease: A Review. JCTCMLB, 2(2):618

Reeves PG; Rossow KL and Lindlauf J (1993):
Development and Testing of the AIN-93 Purified Diets for Rodents: Results on Growth, Kidney Calcification and Bone Mineralization in Rats and Mice. Journal of Nutrition, 123, 1923-1931.

Ripoly E and Norat T (2003): Epidemiologic evidence of the protective effect of fruit and vegetables on cancer risk, Am. J. Clin. Nutr., 78: 559-569.

Roh DD; Kamanna VS and Kirschenbaum MA (1998):

Oxidative modification of lowdensity lipoprotein enhances mesangial cell protein synthesis and gene expression of extracellular matrix proteins. Am $J$ Nephrol.; 18:344-350.

Rudenko G; Henry L; Henderson K; Ichtchenko K; Brown MS; Goldstein JL and Deisenhofer J (2002):

Structure of the LDL receptor extracellular domain at endosomal ph. $J$ of Science; 298:23532358. 
Amal H Emara, Mona S M Kassem, Asmaa S Abd-elwahed, Arij A Yassin and Hanaa H Elsayed

Sahali D; Mulliez N; Chatelet F;

DupuisR; Ronco $P$ and Verroust P (1988):

Characterization of a 280 $\mathrm{Kd}$ protein restricted to the coated pits of the renal brush-border and the epithelial-cells of the yolksac: teratogenic effect of the specific monoclonalantibodies. $J$ Exp Med; 167:213-218.

Salil G and Rajamohan T (2000): Hypolipidemic and antiperoxidative effect of coconut protein in hypercholesterolemic rats. Indian J. Exp. Biol. 39, 1028-1034.

\section{Sandhya VG and Rajamohan T} (2014) :

The role of coconut water on nicotine-induced reproductive dysfunction in experimental male rat model. Food Nutri Sci; 5: 1121-1130

Sandhya VG and Rajamohan T (2008):

Comparative evaluation of the hypolipidemic effects of coconut water and lovastatin in rats fed fatcholesterol enriched diet. Food Chem Toxicol 46:3586-3592.

Sandhya VG and Rajamohan T (2006):

Beneficial effects of coconut water feeding on lipid metabolism in cholesterol fed rats. J. Med. Food 9, 400-407.

Sheyla LM; Heberth P; Maria LP; Rinaldo C; Eduardo L; Deoclecio AC and Marcelo ES (2005).

Dietary Models for Inducing Hypercholesterolemia in Rats. Braz. Arch. Biol. Technol. 48:203-209.

Shin AC; Mohan Kumar SMJ; Balasubramanian P; Sirivelu MP; Linning K; Woolcock A; James M and Mohan Kumar PS (2019):

Responsiveness of hypothalamic pituitary-adrenal axis to leptin is impaired in diet-induced obese rats, Nutrition \& Diabetes 9-19. 
Spoelgen R; Hammes A; Anzenberger U; Zechner A; Zechner D; Andersen OM; Jerchow $B$ and Willnow TE (2005):

$\mathrm{LRP}$ /megalin is required for patterning of the ventral telencephalon.

Development; 132:405415.

Sudhakaran S; Bottiglieri T; Tecson KM; Kluger AY and McCullough PA. (2018):

Alteration of lipid metabolism in chronic kidney disease, the role of novel antihyperlipidemic agents, and future directions. Rev Cardiovasc Med.; 19(3):77-88.

Tang Z; Chen H; He $\mathrm{H}$ and Ma CH (2019):

Assays for alkaline phosphatase activity: Progress and prospects, TrAC Trends in Analytical Chemistry, Volume 113, Pages 32-43

Tietz N W (1986):

Textbook of Clinical Chemistry Edited by N W Tietz. pp 1919. W B
Saunders, Philadelphia. 1986 ISBN 0-7216-8886-1

United States Department of Agriculture (USDA) (2009):

Composition of Foods Raw, Processed, Prepa-red USDA National Nutrient Database for Standard Reference, nuts, coconut water. Release 21, Jaspreet $\mathrm{KC}$; Ahuja, Janice B; Montville, Grace Omolewa-Tomobi; Kaushalya Y, Heendeniya, Carrie L. Martin, Lois C. Steinfeldt, Jaswinder Anand, Meghan E. Adler, Randy P. LaComb, and Alanna J. Moshfegh, U.S. Department of Agriculture. Agricultural Research Service Belts-ville Human Nutrition Research Center Food Surveys Research Group 10300 Baltimore Avenue BARCWest, Building 005, Room 102 Beltsville, Maryland 20705-2350,

Vassault A; Grafmeyer D; de Graeve J; Cohen R; Beaudonnet $A$ and Bienvenu J (2000):

Quality specifications and allowable standards for 
Amal H Emara, Mona S M Kassem, Asmaa S Abd-elwahed, Arij A Yassin and Hanaa H Elsayed

validation of methods used in clinical biochemistry. Ann Biol Clin ; 57(6):68595.

White CR; Parks DA; Patel RP; Shelton J; Tarpey MM; Freeman BA and Darley-Usmar VM (2004):

L-Arginine inhibits xanthine oxidase-dependent endothelial dysfunction in hypercholesterolemia;

FEBS Letters 12; 561(13):94-8.

Wilson SH; Simari RD; Best PJ; Peterson TE; Lerman LO; Aviram M; Nath KA; Holmes DR and Lerman A (2003):

Simvastatin preserves coronary endothelial function in hypercholesterolemia in the absence of lipid lowering. Arterioscler Thromb Vasc Biol. J; 21(1):122-8.

Willet WC (1994):

Diet and health: What should we eat? Science 264, 532-637.

Young DS; Pestaner LC and Gibberman V (1975):
Effects of drugs on clinical laboratory tests; Clin Chem 21(5):1D-432D.

Young DS. (2001):

Effects of disease on Clinical Lab.Tests $4^{\text {th }}$ ed $A A C C$.

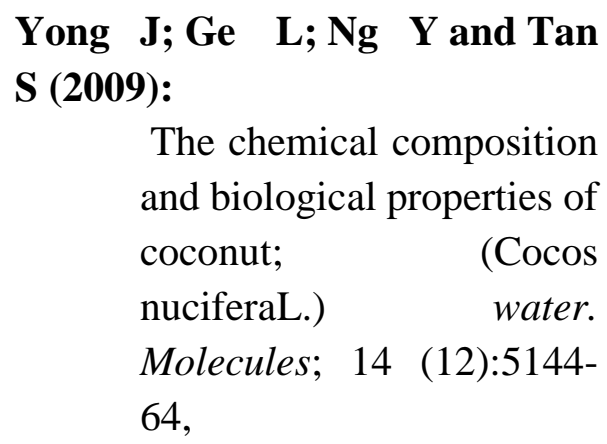

Yong J; Ge L; Ng Y and Tan $S$ (2009):

The chemical composition and biological properties of coconut;

(Cocos nuciferaL.) water. Molecules; 14 (12):514464 ,

Zulaikhah ST; Anies A; Suwondo $A$ and Santosa $B$ (2015):

Effects of tender coconut water on antioxidant enzymatic superoxide dismutase (SOD), catalase (CAT), and glutathione peroxidase (GPx) and lipid peroxidation mercury exposure workers. IJSR 4(2): 517-5 
Table 1: The averages of moisture, protein, fat, ash, fiber and carbohydrate (g/100gm) in coconut liquid

\begin{tabular}{|c|c|}
\hline Parameters & \% of samples \\
\hline Moisture & $95.0 \pm 1.11$ \\
\hline \hline Protein & $0.86 \pm 0.015$ \\
\hline Fat & $0.30 \pm 0.002$ \\
\hline Ash & $0.34 \pm 0.003$ \\
\hline Fiber & $0.89 \pm 0.001$ \\
\hline Carbohydrate & 2.61 \\
\hline
\end{tabular}

Each value represented as mean \pm SD. All determination was performed in triplicates.

Table (2): DPPH scavenging activity of coconut Liquid.

\begin{tabular}{|l|c|c|c|c||c||}
\hline \multirow{3}{*}{$\begin{array}{c}\text { Fresh } \\
\text { sample }\end{array}$} & \multicolumn{4}{|c||}{ Scavenging free radicle \% } & Total phenolic \\
\cline { 2 - 5 } & $\mathbf{1 ~} \mathbf{~ m l}$ & $\mathbf{2 m l}$ & $\mathbf{3 m l}$ & $\mathbf{4 m l}$ & $\begin{array}{c}50 \mu \mathrm{g} / \mathrm{ml} \\
\text { sample }\end{array}$ \\
\cline { 2 - 5 } & $\mathbf{8 2 \pm 2 . 2 2}$ & $\mathbf{9 4} \pm \mathbf{6}$ & $\mathbf{9 8} \pm \mathbf{6}$ & $\mathbf{9 9} \pm \mathbf{5}$ & \\
\hline
\end{tabular}


Table (3) Elements level of coconut water

\begin{tabular}{|c||c||c||c|}
\hline Elements & $\begin{array}{c}\text { Concentration/ } \\
\text { Ppm }\end{array}$ & Elements & $\begin{array}{c}\text { Concentration/ } \\
\text { ppm }\end{array}$ \\
\hline $\mathbf{N a}$ & $12.50 \pm 0.012$ & $\mathrm{Mg}$ & $21.50 \pm 0.016$ \\
\hline $\mathbf{K}$ & $295 \pm 3.012$ & $\mathrm{Mn}$ & $4.30 \pm 0.006$ \\
\hline $\mathbf{C a}$ & $10 \pm 0.010$ & $\mathrm{Fe}$ & $1.43 \pm 0.002$ \\
\hline $\mathbf{P}$ & $85.50 \pm 1.01$ & $\mathrm{Zn}$ & $0.80 \pm 0.001$ \\
\hline $\mathbf{C u}$ & \multicolumn{3}{|c|}{$0.16 \pm 0.002$} \\
\hline
\end{tabular}

Each value represented as mean $\pm S D$. All determinations were performed in triplicates.

Table (4) Vitamins content of coconut liquid:

\begin{tabular}{|c|c|}
\hline Vitamins & Content $(\mathbf{p p m})$ \\
\hline \hline Vitamin $\mathbf{B}_{\mathbf{1}}$ & $0.790 \pm 0.011$ \\
\hline Vitamin $\mathbf{B}_{\mathbf{2}}$ & $0.581 \pm 0.008$ \\
\hline Vitamin $\mathbf{C}$ & $0.592 \pm 0.009$ \\
\hline Vitamin A & 0.000 \\
\hline
\end{tabular}

All determinations performed in triplicates each value represented as mean $\pm S D$. 


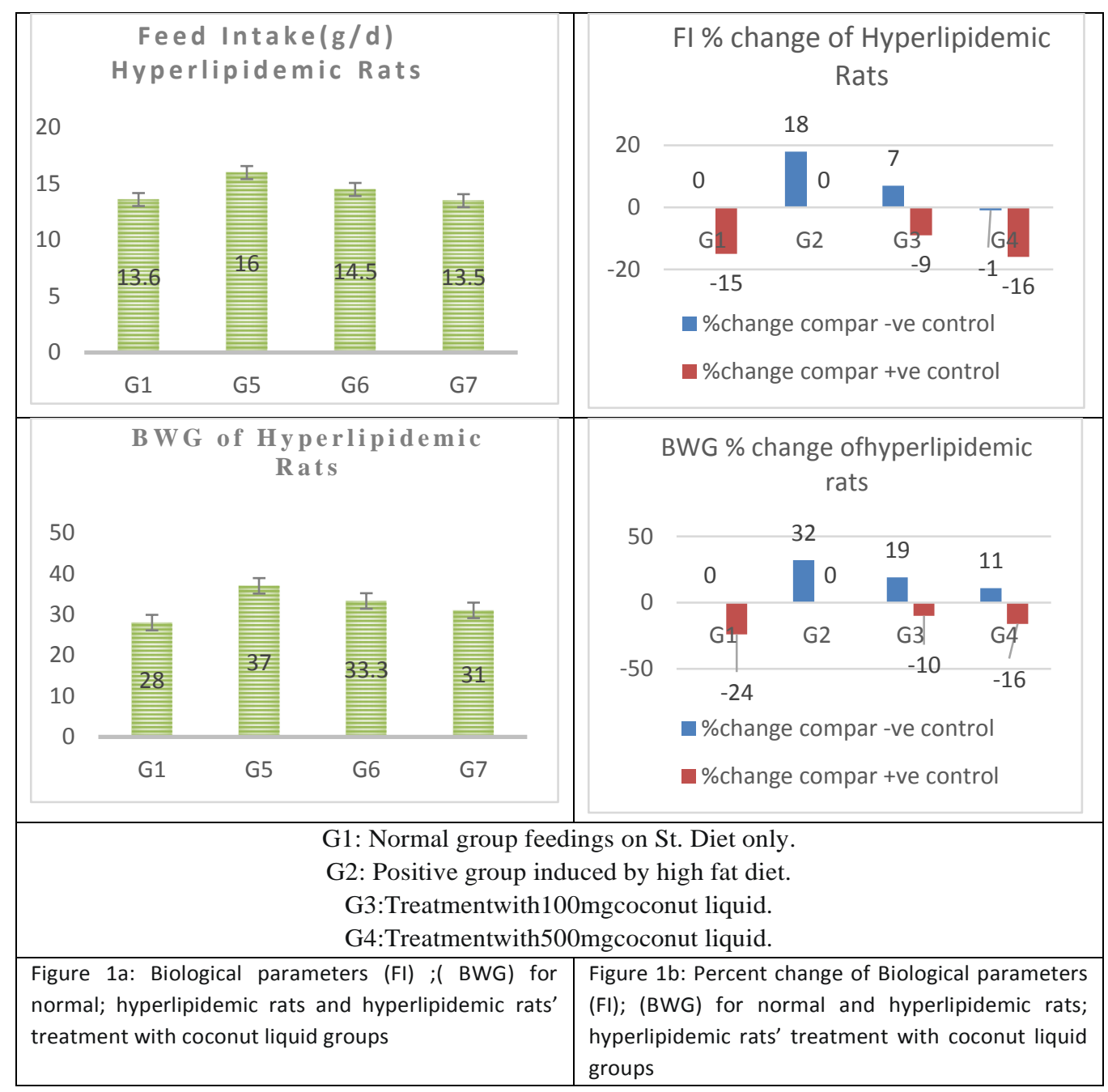


Amal H Emara, Mona S M Kassem, Asmaa S Abd-elwahed, Arij A Yassin and Hanaa H Elsayed

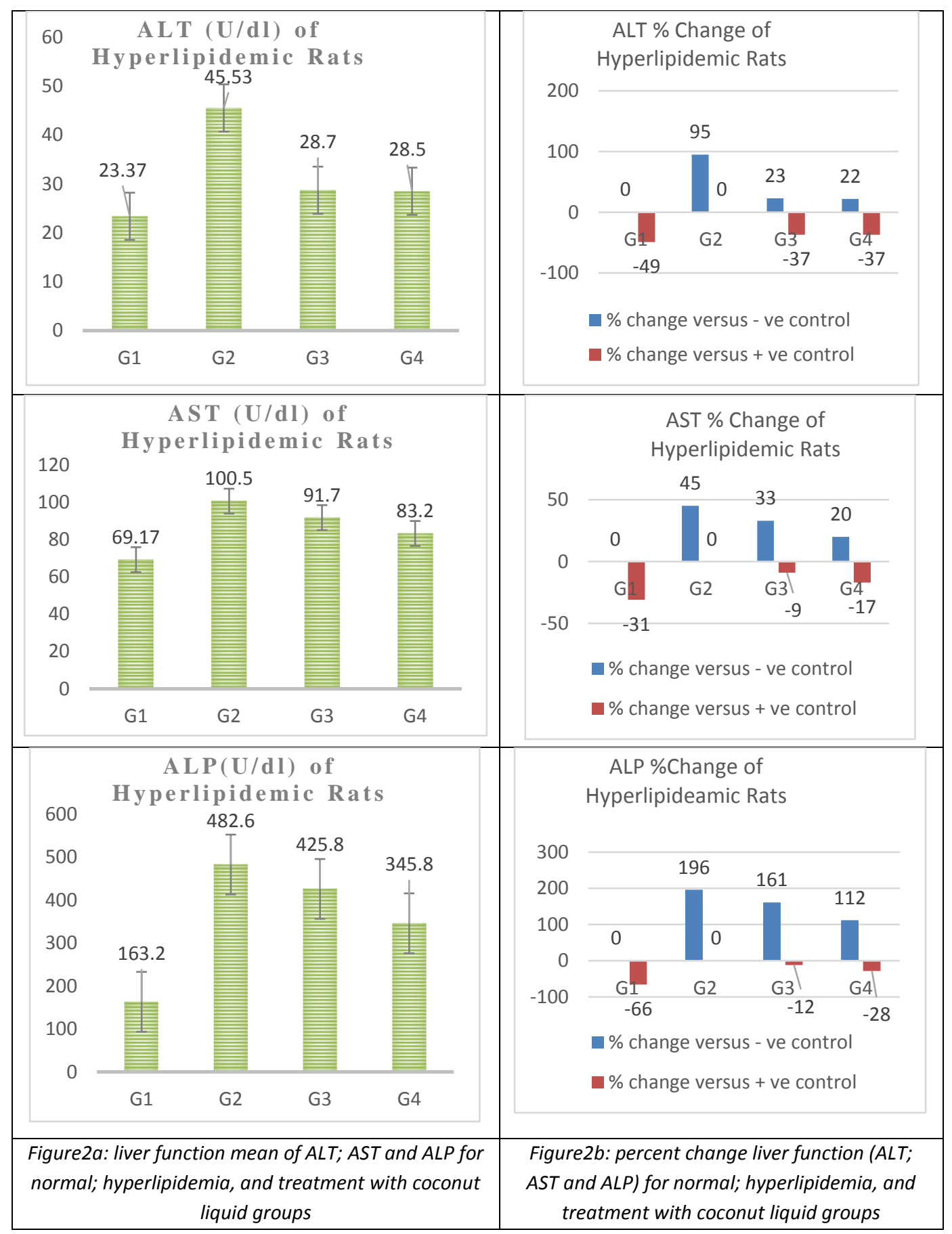

Bulletin of the National Nutrition Institute of the Arab Republic of Egypt. June 2021 (57) 32 


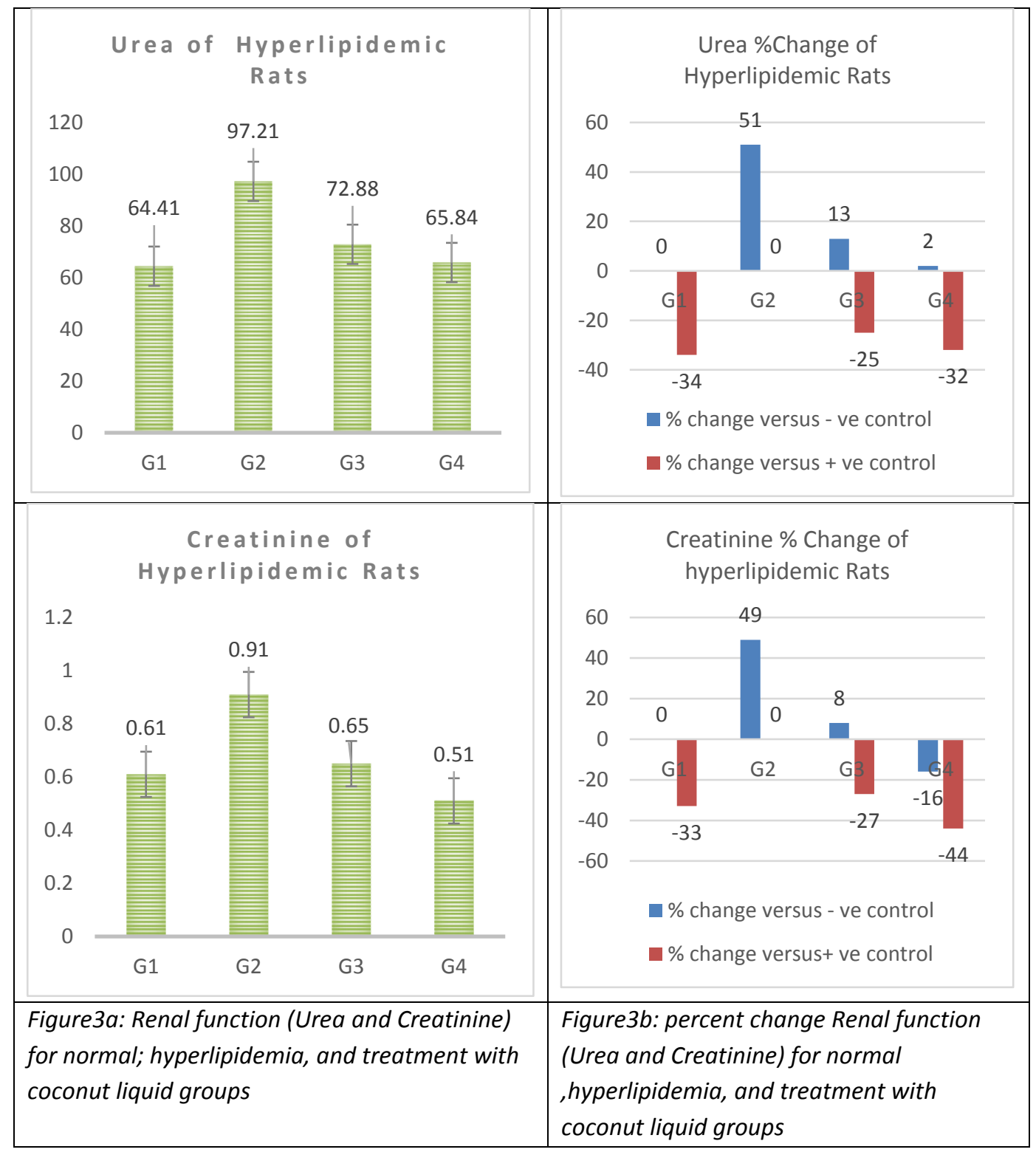

Bulletin of the National Nutrition Institute of the Arab Republic of Egypt. June 2021 (57) 33 
Amal H Emara, Mona S M Kassem, Asmaa S Abd-elwahed, Arij A Yassin and Hanaa H Elsayed

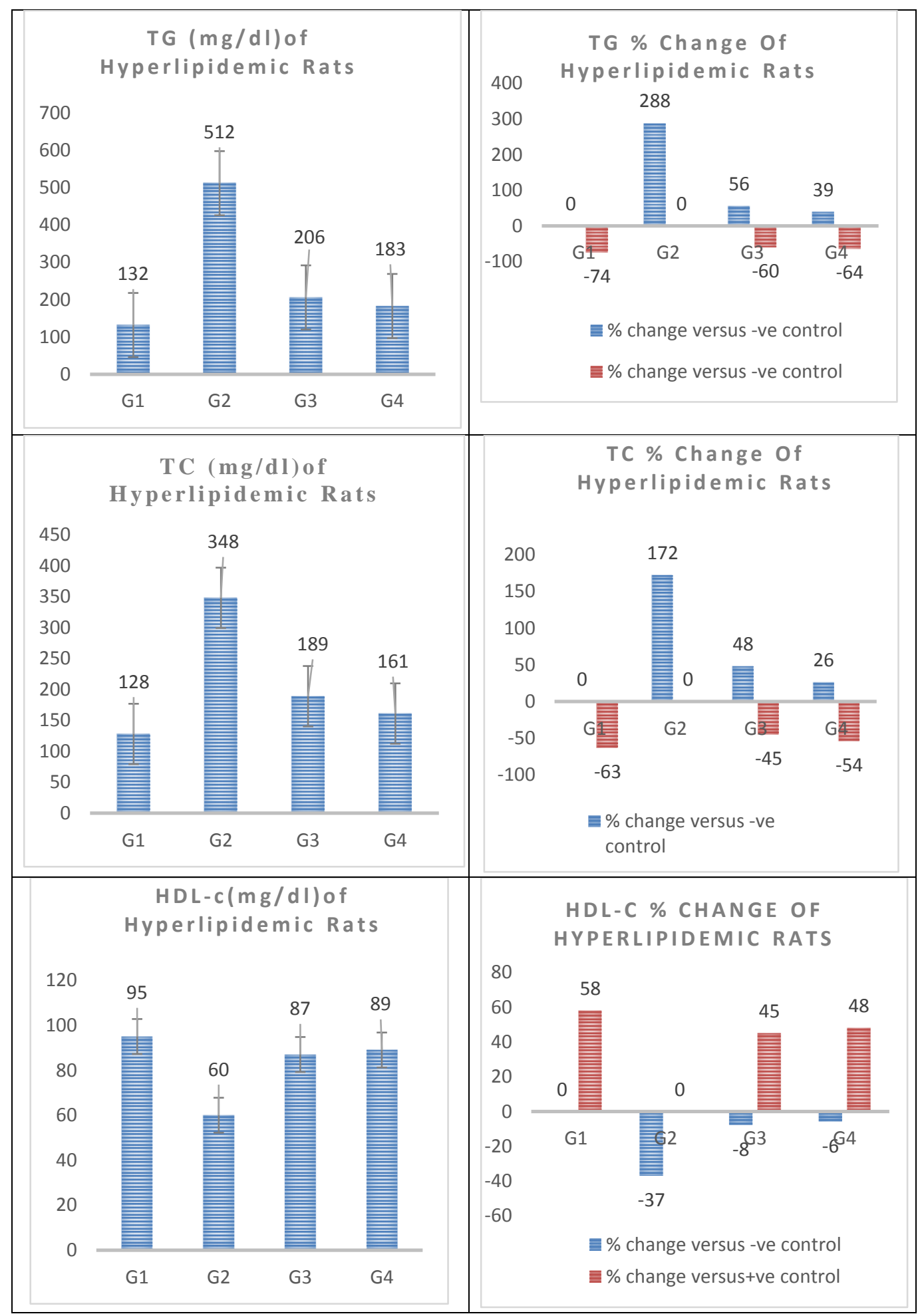

Bulletin of the National Nutrition Institute of the Arab Republic of Egypt. June 2021 (57) 34 
Amal H Emara, Mona S M Kassem, Asmaa S Abd-elwahed, Arij A Yassin and Hanaa H Elsayed

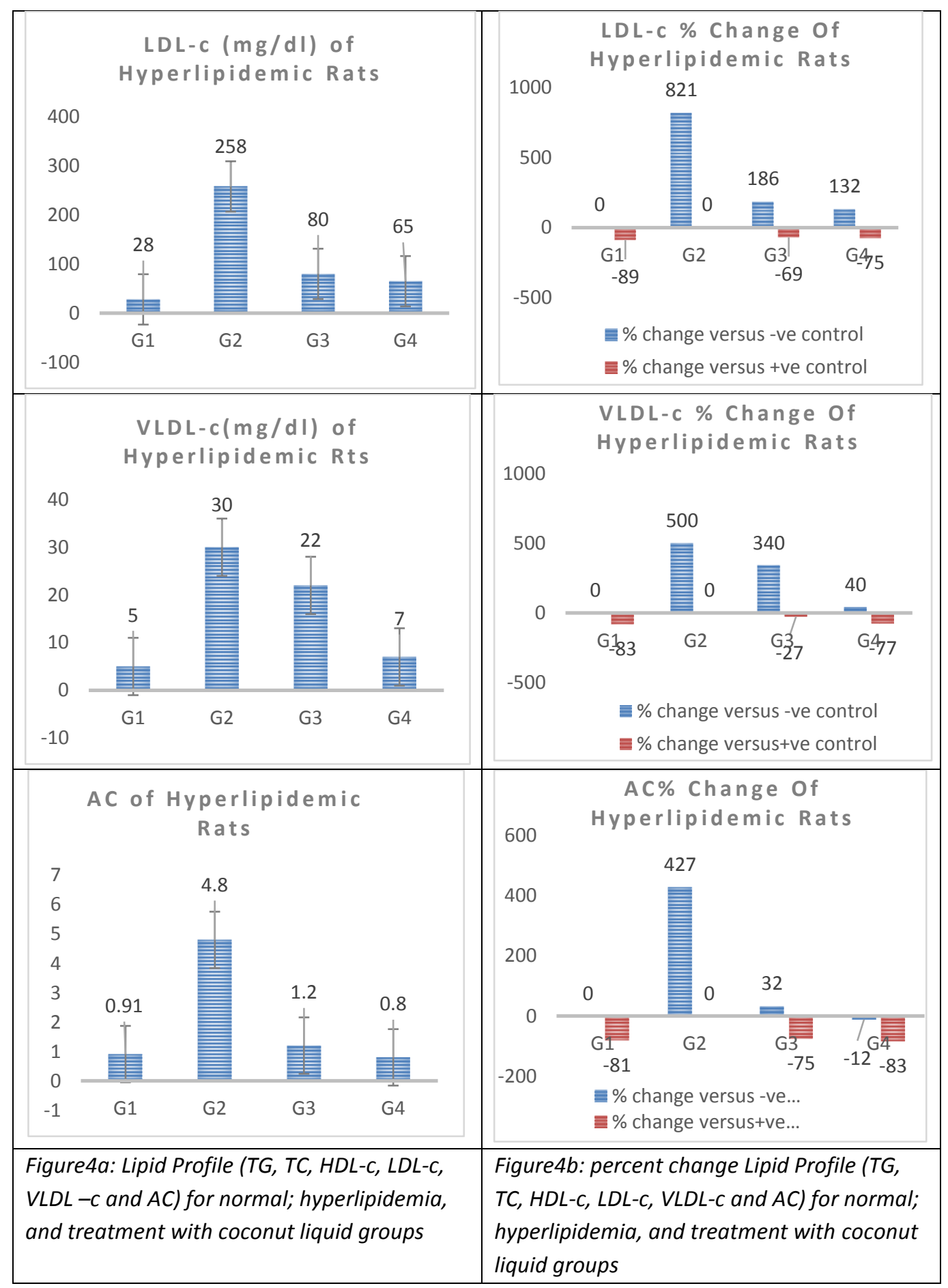

Bulletin of the National Nutrition Institute of the Arab Republic of Egypt. June 2021 (57) 35 


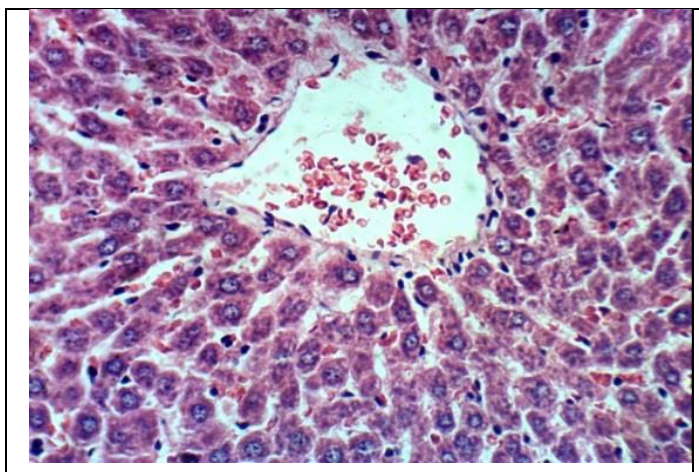

Photo1: Normal group feeding standard diet only. Liver of rat from group 1 showing the normal histological structure of hepatic lobule

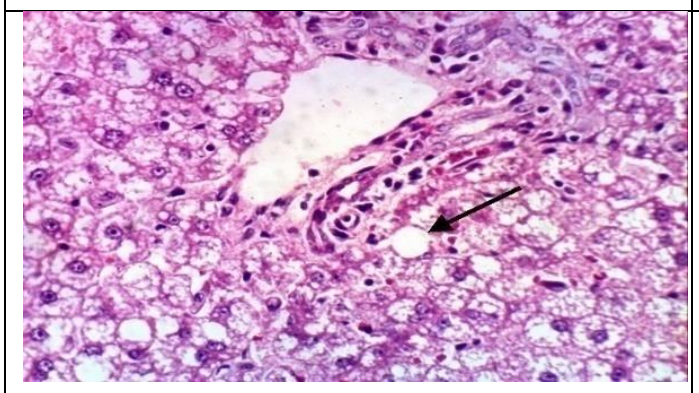

Photo3: Treatment with 100mg coconut liquid shows a decrease in liver cell degeneration

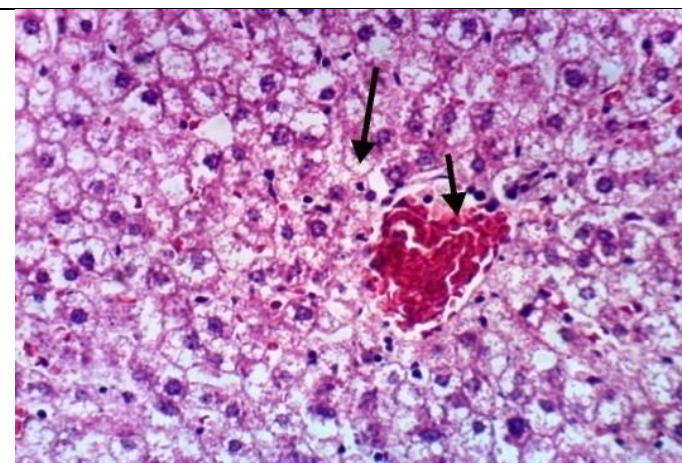
photo2: Positive control fed high fat diet Liver of rat showing congestion of central vein and steatosis of hepatocytes

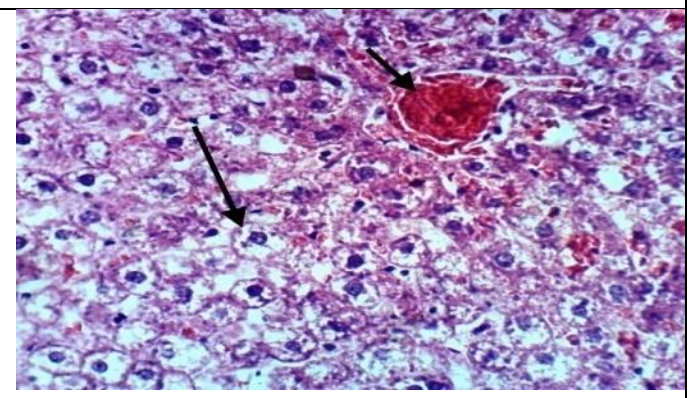

photo 4: Treatment with 500mg coconut liquid showing cytoplasmic vacuolization of hepatocytes and congestion of central vein

Figure (5) Liver histological examinations for normal; hyperlipidemia and hyperlipidemic treatment with coconut liquid groups. 


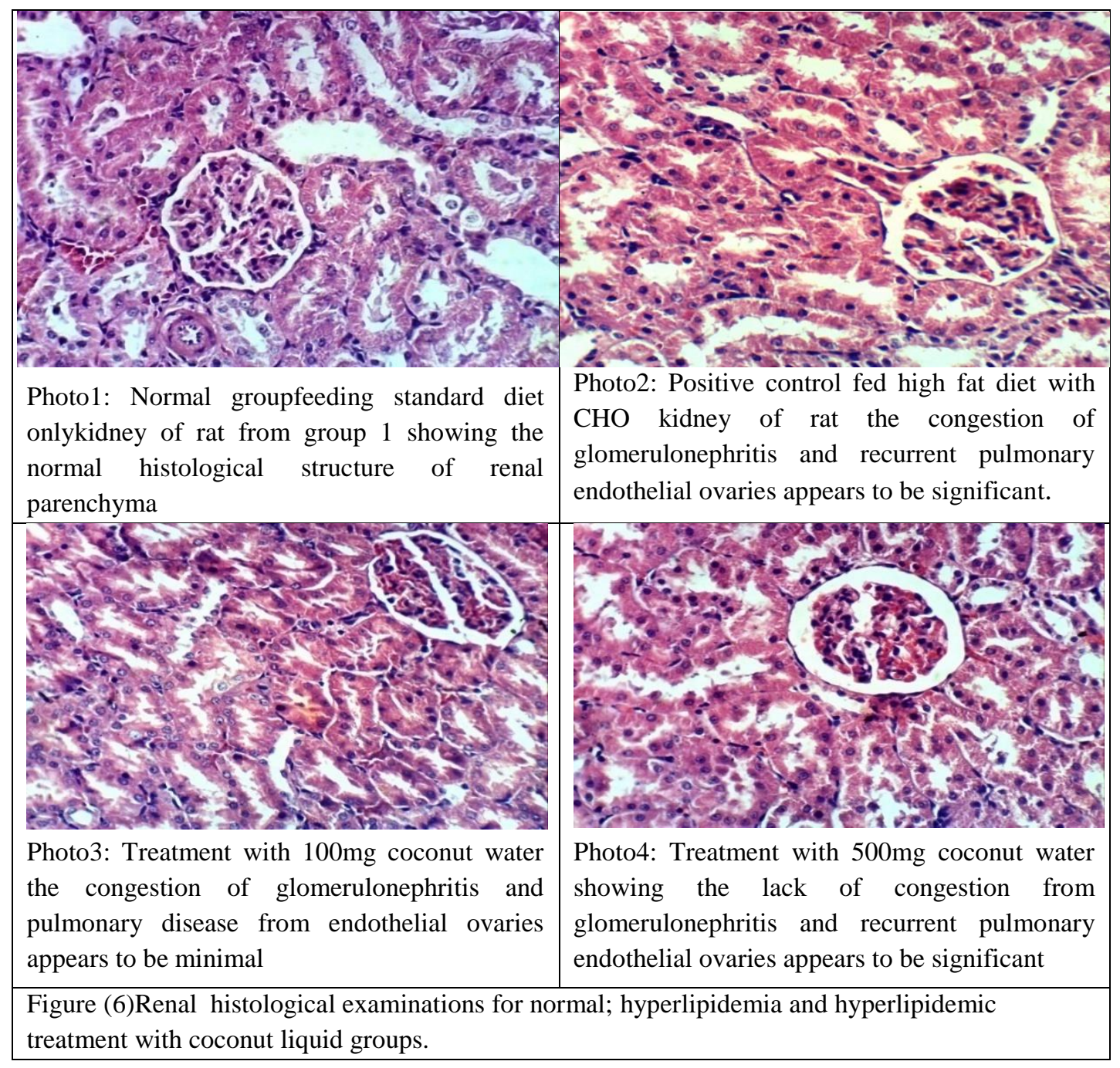




\section{التدخل الغذائي بسائل جوز الهزد للحد من زيادة

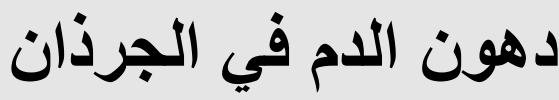

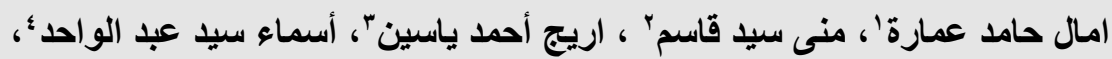

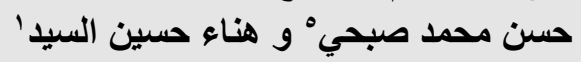

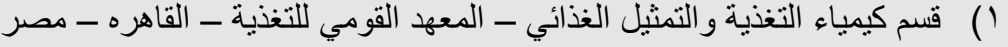

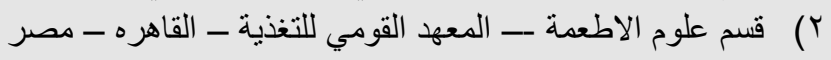

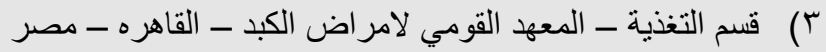

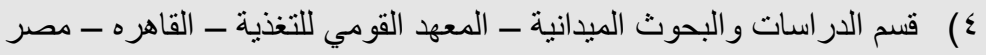

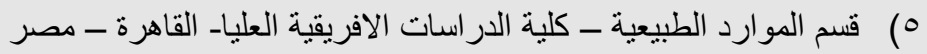

\section{الملخص العربي}

يحتوي سـائل جوز الهند كمشـروب طبيعي على العدبيد من العناصـر الغذائية النشـــة

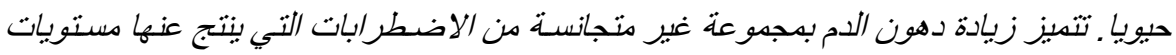

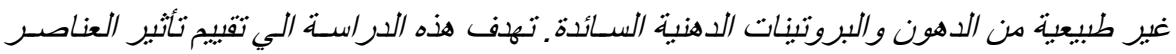

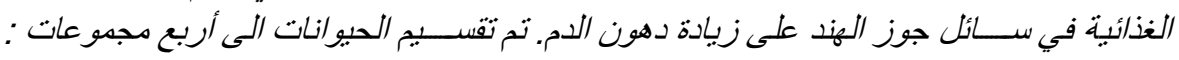

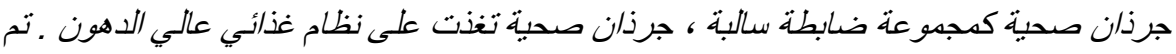

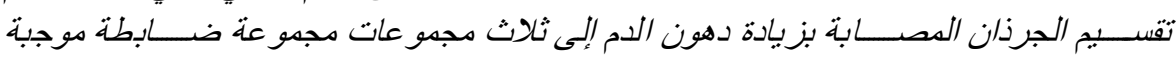

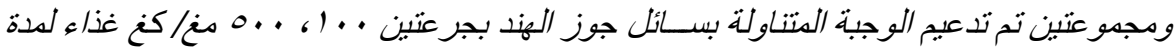

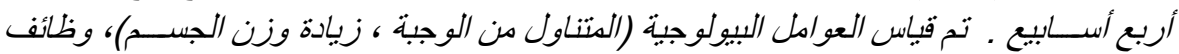

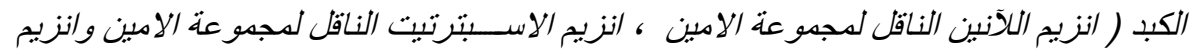

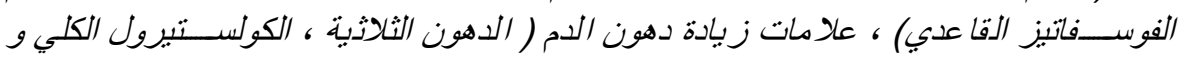

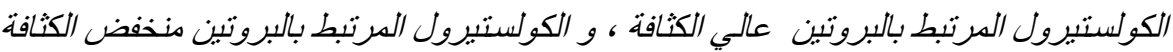

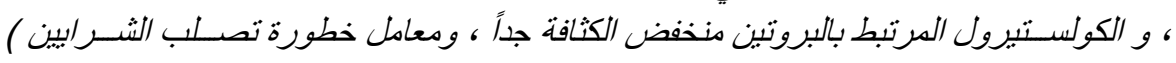

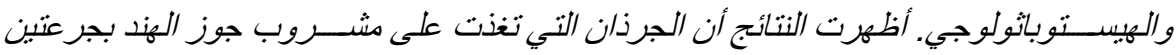

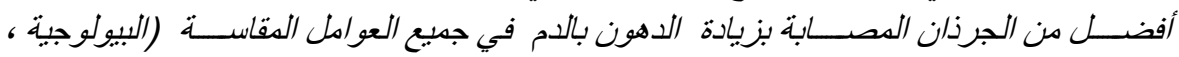

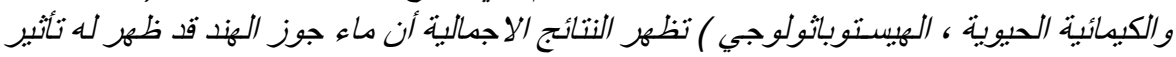

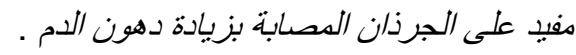
الكلمات المفتاحية : سائل جوز الهند - ارتفاع الدهون في الدم ـ التدخل الغذائي 